MODIFIED COSTING TOOL FOR 'WHERE WILL IT END' STUDY V1.8 FINAL

Prepared by Thomas HA Samuels

\begin{tabular}{|c|c|c|}
\hline Question/field & $\mathbf{Q}$ & Options \\
\hline Interview setup & & \\
\hline $\begin{array}{l}\text { (question for interviewer) } \\
\text { Interviewer initials }\end{array}$ & 1 & \\
\hline $\begin{array}{l}\text { (question for interviewer) } \\
\text { Date of the interview }\end{array}$ & 2 & Drop down calendar \\
\hline $\begin{array}{l}\text { (question for interviewer) } \\
\text { Generate new participant ID }\end{array}$ & 3 & Generate new ID number. \\
\hline \multicolumn{3}{|l|}{ Personal Details } \\
\hline What is your surname? & 4 & \\
\hline And your first/Christian name? & 5 & \\
\hline How old are you? & 6 & \\
\hline What is your gender? & 7 & $\begin{array}{l}\text { Male } \\
\text { Female }\end{array}$ \\
\hline $\begin{array}{l}\text { Which district do you live in? } \\
\text { Which county? } \\
\text { Which sub-county? (if relevant) } \\
\text { Which parish? } \\
\text { Which village? }\end{array}$ & 8 & $\begin{array}{l}\text { District (free text) } \\
\text { County (free text) } \\
\text { Sub-county (free text) } \\
\text { Parish (free text) } \\
\text { Village (free text) }\end{array}$ \\
\hline $\begin{array}{l}\text { (Question for interviewer) } \\
\text { Is the participants address in an urban or rural location? If they have } \\
\text { moved since testing, what location was it in at time of testing? }\end{array}$ & 9 & $\begin{array}{l}\text { Rural } \\
\text { Urban }\end{array}$ \\
\hline $\begin{array}{l}\text { (Question for interviewer) } \\
\text { Is the patient alive or dead? }\end{array}$ & 10 & $\begin{array}{l}\text { Alive } \\
\text { Dead } \\
\text { If answer is alive, complete rest of questionnaire. If answer is } \\
\text { dead, answer questions labelled } \Omega \text { then stop questionnaire }\end{array}$ \\
\hline Do you own a mobile phone? & 11 & $\begin{array}{c}\text { Yes } \\
\text { No } \\
\end{array}$ \\
\hline
\end{tabular}




\begin{tabular}{|c|c|c|}
\hline $\begin{array}{l}\text { (If conducting phone interview, interviewer to answer yes without } \\
\text { asking participant) }\end{array}$ & & \\
\hline $\begin{array}{l}\text { If so, what is your mobile phone number? } \\
\text { (starting with } 0 \text {; do not use }+256 \text { ) }\end{array}$ & 12 & $\begin{array}{c}\text { To be displayed only if the answer to the previous question is } \\
\text { yes }\end{array}$ \\
\hline TB testing & & \\
\hline $\begin{array}{l}\text { Before you had testing for TB, how many times did you seek health } \\
\text { care or advice for your symptoms? }\end{array}$ & 13 & \\
\hline $\begin{array}{l}\text { And which of the following did you access? } \\
\text { For other and don't know, please specify the name or names of the } \\
\text { facility: }\end{array}$ & 14 & $\begin{array}{c}\text { Health centre I - II } \\
\text { Health centre III - IV } \\
\text { District Hospital } \\
\text { Referral Hospital } \\
\text { Local pharmacy/drugstore } \\
\text { Dispensary } \\
\text { Herbalist } \\
\text { Traditional practitioner } \\
\text { Private clinic or hospital } \\
\text { Community health worker } \\
\text { Other (specify free text) } \\
\text { Don't know (specify free text) }\end{array}$ \\
\hline $\begin{array}{l}\text { (Question for interviewer - using registry data) } \\
\text { In which of the following locations was the participant tested for TB? }\end{array}$ & $\begin{array}{l}15 \\
\Omega\end{array}$ & $\begin{array}{c}\text { Selected test centres (TBC) } \\
1- \\
2- \\
3- \\
4-\end{array}$ \\
\hline $\begin{array}{l}\text { (Question for interviewer - using registry data) } \\
\text { When was that test done? }\end{array}$ & $\begin{array}{l}16 \\
\Omega\end{array}$ & Drop down calendar \\
\hline $\begin{array}{l}\text { (Question for interviewer - using registry data) } \\
\text { What method of TB testing was used? }\end{array}$ & $\begin{array}{l}17 \\
\Omega\end{array}$ & $\begin{array}{c}\text { GeneXpert } \\
\text { Smear microscopy }\end{array}$ \\
\hline $\begin{array}{l}\text { Were you told what the result of your TB test was? } \\
\text { (If no, and participant has not already been given results of testing, ask } \\
\text { whether participant would like their results. If they agree, give the } \\
\text { negative result.) }\end{array}$ & 18 & $\begin{array}{l}\text { Yes } \\
\text { No }\end{array}$ \\
\hline What symptoms did you have when you were tested? & 19 & $\begin{array}{c}\text { Cough } \\
\text { Shortness of breath }\end{array}$ \\
\hline
\end{tabular}




\begin{tabular}{|c|c|c|}
\hline If other, please specify: & & $\begin{array}{c}\text { Fever } \\
\text { Weight loss } \\
\text { Night sweats } \\
\text { Other (specify free text) }\end{array}$ \\
\hline $\begin{array}{l}\text { How long did your symptoms continue after TB testing? (in weeks) } \\
\text { (If less than a week, record as "1") }\end{array}$ & 20 & \\
\hline $\begin{array}{l}\text { Since your test, have you tested positive for, or been started on } \\
\text { treatment for, TB? } \\
\text { (Can confirm on district registers) }\end{array}$ & 21 & $\begin{array}{l}\text { No } \\
\text { Yes, not on treatment } \\
\text { Yes, on treatment }\end{array}$ \\
\hline Did you know your HIV status at the time of your initial TB testing? & 22 & $\begin{array}{l}\text { Yes } \\
\text { No } \\
\end{array}$ \\
\hline If so, what was your HIV status? & $\begin{array}{c}23 \\
\Omega\end{array}$ & $\begin{array}{l}\text { Field only to open if answer to previous question is Yes } \\
\qquad \begin{array}{c}\text { Positive } \\
\text { Negative }\end{array}\end{array}$ \\
\hline \multicolumn{3}{|l|}{ Healthcare sought after testing } \\
\hline $\begin{array}{l}\text { Have you sought further healthcare or other advice about your } \\
\text { symptoms since TB testing? }\end{array}$ & 24 & $\begin{array}{l}\text { Yes } \\
\text { No }\end{array}$ \\
\hline $\begin{array}{l}\text { How many times have you sought advice since your negative test? } \\
\text { If the answer to the previous question is No, then enter answer " } 0 \text { ". }\end{array}$ & $\begin{array}{l}25 \\
\Delta \Delta\end{array}$ & $\begin{array}{l}\text { Answer to this question will determine how many repetitions of } \\
\text { Questions } 60 \text { to } 77 \text { will be administered. }\end{array}$ \\
\hline $\begin{array}{l}\text { Did you have any further investigations done or treatment given by the } \\
\text { clinic that did your TB test? }\end{array}$ & 26 & $\begin{array}{l}\text { Yes } \\
\text { No }\end{array}$ \\
\hline If yes, what were they? & 27 & $\begin{array}{l}\text { To be displayed if answer to previous question is Yes } \\
\qquad \text { Chest X-ray } \\
\text { Examined by doctor } \\
\text { Antibiotics given } \\
\text { Referral made to another hospital }\end{array}$ \\
\hline Have you found a cause for your symptoms? & $\begin{array}{l}28 \\
\wedge \wedge \\
\end{array}$ & $\begin{array}{c}\text { Yes } \\
\text { No } \\
\end{array}$ \\
\hline If yes, what was the cause? & 29 & Field only to open if answer to question 28 is Yes \\
\hline
\end{tabular}




\begin{tabular}{|c|c|c|}
\hline $\begin{array}{l}\text { And who gave you the answer? } \\
\text { For other and don't know, please specify name of facility: }\end{array}$ & 30 & $\begin{array}{l}\text { Field only to open if answer to question } 28 \text { is yes: } \\
\qquad \begin{array}{c}\text { Health centre I - II } \\
\text { Health centre III - IV } \\
\text { District Hospital } \\
\text { Referral Hospital } \\
\text { Local pharmacy/drugstore } \\
\text { Dispensary } \\
\text { Herbalist } \\
\text { Traditional practitioner } \\
\text { Private clinic or hospital } \\
\text { Community health worker } \\
\text { Other (specify free text) } \\
\text { Don't know (specify free text) }\end{array}\end{array}$ \\
\hline If no, what stopped you finding an answer? & 31 & Field only to open if answer to question 28 is no \\
\hline \multicolumn{3}{|l|}{ Income reported before developing symptoms } \\
\hline $\begin{array}{l}\text { What was your primary employment, or normal work, before your } \\
\text { symptoms started? } \\
\text { Please specify other: }\end{array}$ & 32 & $\begin{array}{c}\text { School student } \\
\text { Technician (vocational training in automotives, health care, } \\
\text { etc.) } \\
\text { Service (maid, driver etc.) } \\
\text { Factory worker } \\
\text { Farmer } \\
\text { Government employee (office admin) } \\
\text { Teacher } \\
\text { Retiree } \\
\text { Housewife/homemaker } \\
\text { Casual labourer } \\
\text { Security/Police/Guard } \\
\text { Unemployed } \\
\text { Other (specify free text) }\end{array}$ \\
\hline $\begin{array}{l}\text { If you were in paid work, how much do you estimate your average net } \\
\text { wage from labour related activities (labour income), per month was } \\
\text { before your symptoms started? (USh/month) }\end{array}$ & 33 & \\
\hline
\end{tabular}




\begin{tabular}{|c|c|c|}
\hline If not in paid work or no income, enter "0" & & \\
\hline $\begin{array}{l}\text { How many hours a week were you working before your symptoms } \\
\text { started? (hours per week) } \\
\text { If not working, enter "0" }\end{array}$ & 34 & \\
\hline $\begin{array}{l}\text { How much do you estimate the average revenue from labour (income), } \\
\text { after tax, of your household was per month, before your symptoms } \\
\text { started? (USh/month) }\end{array}$ & 35 & \\
\hline Income changes and social consequences & & \\
\hline $\begin{array}{l}\text { What is your current primary employment, or normal work, or normal } \\
\text { other main activity? } \\
\text { Please specify other: }\end{array}$ & 36 & $\begin{array}{c}\text { School student } \\
\text { Technician (vocational training in automotives, health care, } \\
\text { etc.) } \\
\text { Service (maid, driver etc.) } \\
\text { Factory worker } \\
\text { Farmer } \\
\text { Government employee (office admin) } \\
\text { Teacher } \\
\text { Retiree } \\
\text { Housewife/homemaker } \\
\text { Casual labourer } \\
\text { Security/Police/Guard } \\
\text { Unemployed } \\
\text { Other (specify free text) }\end{array}$ \\
\hline $\begin{array}{l}\text { If you are in paid work, how much do you currently estimate your } \\
\text { average net wage from labour related activities (net labour income), } \\
\text { per month is now? (USh/month) If not working, enter "0". }\end{array}$ & 37 & \\
\hline $\begin{array}{l}\text { How much do you estimate the average revenue from labour (net } \\
\text { labour income), after tax, of your household is per month now? } \\
\text { (USh/month) }\end{array}$ & 38 & \\
\hline $\begin{array}{l}\text { How many hours per week are you working now? (hours/week) If not } \\
\text { working, enter "0". }\end{array}$ & 39 & \\
\hline $\begin{array}{l}\text { Approximately how many working days of income have you lost due to } \\
\text { your symptoms after you were tested for TB? (days) }\end{array}$ & 40 & \\
\hline $\begin{array}{l}\text { Did you or your household receive any social welfare payment for } \\
\text { health-related issues since the negative test for TB? }\end{array}$ & 41 & $\begin{array}{l}\text { No } \\
\text { Yes }\end{array}$ \\
\hline
\end{tabular}




\begin{tabular}{|c|c|c|}
\hline & & If answer is no, skip to Question 46 \\
\hline $\begin{array}{l}\text { Paid sick leave: amount (after tax) during the last month (USh/month) } \\
\text { If did not receive, enter "0" }\end{array}$ & 42 & \\
\hline $\begin{array}{l}\text { Disability grant: amount (after tax) during the last month (USh/month) } \\
\text { If did not receive, enter " } 0 \text { " }\end{array}$ & 43 & \\
\hline $\begin{array}{l}\text { Cash transfer for poor families: amount (after tax) during the last month } \\
\text { (USh/month) } \\
\text { If did not receive, enter "0" }\end{array}$ & 44 & \\
\hline $\begin{array}{l}\text { Other cash transfer: amount (after tax) during the last month } \\
\text { (USh/month) } \\
\text { If did not receive, enter "0" }\end{array}$ & 45 & \\
\hline $\begin{array}{l}\text { Did you or your household use any savings (cash or bank deposits) to } \\
\text { cover costs due to your symptoms after your negative TB test? }\end{array}$ & 46 & 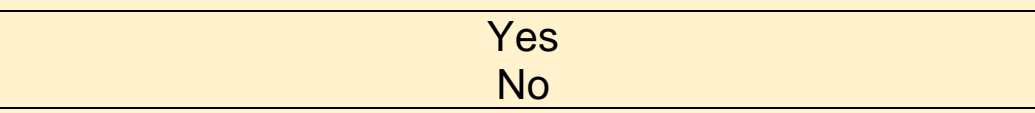 \\
\hline If yes, how much did you use in total? (USh) & 47 & Field only to open if answer to previous question is yes \\
\hline $\begin{array}{l}\text { Did you borrow any money to cover costs due to your symptoms after } \\
\text { your negative TB test? }\end{array}$ & 48 & $\begin{array}{l}\text { Yes } \\
\text { No }\end{array}$ \\
\hline If yes, how much did you borrow in total? (USh) & 49 & Field only to open if answer to previous question is yes \\
\hline $\begin{array}{l}\text { From whom did you borrow? } \\
\text { If other, please specify: }\end{array}$ & 50 & $\begin{array}{l}\text { Field only to open if answer to question } 48 \text { is yes } \\
\qquad \text { Family } \\
\text { Neighbours/friends } \\
\text { Private bank } \\
\text { Cooperative employer } \\
\text { "Unofficial/Money lender" (Black Market) } \\
\text { Other (specify free text) }\end{array}$ \\
\hline Are you expected to pay the loan back? & 51 & $\begin{array}{l}\text { Field only to open if answer to question } 48 \text { is yes } \\
\text { Yes } \\
\text { No }\end{array}$ \\
\hline Have you started paying back the loan? & 52 & Field only to open if answer to question 48 is yes \\
\hline Modified Costing Tool & $3 \mathrm{Ju}$ & Page 6 of \\
\hline
\end{tabular}




\begin{tabular}{|c|c|c|}
\hline & & $\begin{array}{l}\text { Yes } \\
\text { No }\end{array}$ \\
\hline $\begin{array}{l}\text { What is the monthly repayment on the loan, including interest? } \\
\text { (USh/month) }\end{array}$ & 53 & Field only to open if answer to question 48 is yes \\
\hline $\begin{array}{l}\text { Have you sold any property to finance the cost of your illness since } \\
\text { your negative TB test? }\end{array}$ & $\begin{array}{l}54 \\
\star *\end{array}$ & $\begin{array}{l}\text { Yes } \\
\text { No }\end{array}$ \\
\hline If yes, what did you sell? & 55 & $\begin{array}{l}\text { Field only to open if answer to question } 54 \text { is yes } \\
\qquad \begin{array}{c}\text { Land } \\
\text { Livestock } \\
\text { Vehicle } \\
\text { Household item } \\
\text { Farm produce } \\
\text { Gold/jewellery } \\
\text { Other (specify free text) }\end{array}\end{array}$ \\
\hline $\begin{array}{l}\text { How much money did you receive from the sale of all items of your } \\
\text { property in total? (USh) }\end{array}$ & 56 & Field only to open if answer to question 54 is yes \\
\hline $\begin{array}{l}\text { Were the assets that you sold previously supporting the family income } \\
\text { (or expenditure)? }\end{array}$ & 57 & $\begin{array}{c}\text { Field only to open if answer to question } 54 \text { is yes } \\
\text { Yes } \\
\text { No }\end{array}$ \\
\hline $\begin{array}{l}\text { If yes, indicate monthly income previously generated by the assets: } \\
\text { (USh/month) }\end{array}$ & 58 & $\begin{array}{l}\text { Field only to open if answer to question } 54 \text { is yes and the } \\
\text { answer to question } 57 \text { is yes }\end{array}$ \\
\hline $\begin{array}{l}\text { To what extent have the symptoms/illness affected the household } \\
\text { financially? }\end{array}$ & 59 & $\begin{array}{c}\text { No impact } \\
\text { Little impact } \\
\text { Moderate impact } \\
\text { Serious impact } \\
\text { Very serious impact }\end{array}$ \\
\hline $\begin{array}{l}\text { Review of visits to facilities after TB testing } \\
\text { The following set of questions, shaded grey, need to be repeated a } \\
\text { number of times defined by the answer to question } 25 \text { (marked } \Delta \Delta \text { ). }\end{array}$ & & $\begin{array}{l}\text { Each successive round will be labelled by sequential letters (a- } \\
\text { z) }\end{array}$ \\
\hline $\begin{array}{l}\text { For this visit to another facility for care or advice for your symptoms, } \\
\text { what type of facility did you visit? } \\
\text { If other or unknown, please enter the name of the facility. }\end{array}$ & $60 a$ & $\begin{array}{l}\text { Health centre I - II } \\
\text { Health centre III - IV } \\
\text { District Hospital } \\
\text { Referral Hospital }\end{array}$ \\
\hline
\end{tabular}




\begin{tabular}{|c|c|c|}
\hline & & $\begin{array}{c}\text { Local pharmacy/drugstore } \\
\text { Dispensary } \\
\text { Herbalist } \\
\text { Traditional practitioner } \\
\text { Private clinic or hospital } \\
\text { Community health worker } \\
\text { Other (specify free text) } \\
\text { Don't know (specify free text) }\end{array}$ \\
\hline $\begin{array}{l}\text { How many weeks after TB testing did you visit this provider? (weeks } \\
\text { after) }\end{array}$ & $61 \mathrm{a}$ & \\
\hline $\begin{array}{l}\text { How much total travel time to and from the facility did you spend } \\
\text { visiting this provider? }\end{array}$ & $62 a$ & \\
\hline $\begin{array}{l}\text { How much total time did you spend visiting this provider? Include } \\
\text { waiting times, consultations, waiting for any lab results, etc. }\end{array}$ & $63 a$ & \\
\hline $\begin{array}{l}\text { Did you spend any out-of-pocket money on medical expenses including } \\
\text { consultation fees, testing, medicines, or other items such as nutritional } \\
\text { supplements? }\end{array}$ & $64 a$ & $\begin{array}{c}\text { Yes } \\
\text { No }\end{array}$ \\
\hline $\begin{array}{l}\text { What is the TOTAL amount of ALL money and goods (including all } \\
\text { things that were borrowed, sold or traded) that you and any other } \\
\text { people in your household plus any guardians or caregivers had to use, } \\
\text { that you or they would not have had to if you never had these } \\
\text { symptoms or had to visit this provider? (USh) }\end{array}$ & $65 a$ & \\
\hline $\begin{array}{l}\text { How much out-of-pocket money did you spend during this visit for: } \\
\text { DAY CHARGES? } \\
\text { (Fees for hospital days. Only for hospitalisations, and only to be filled if } \\
\text { not covered by the cost items below (consultation fee etc.)). If } \\
\text { participant was never hospitalised, write "0". (USh) }\end{array}$ & $66 a$ & \\
\hline $\begin{array}{l}\text { How much out-of-pocket money did you spend during this visit for: } \\
\text { CONSULTATION FEES? } \\
\text { (Other charges, not covered under day charge, including direct } \\
\text { payments to health care staff) (USh) }\end{array}$ & $67 a$ & \\
\hline How much out-of-pocket money did you spend during this visit for: & $68 a$ & \\
\hline
\end{tabular}


RADIOGRAPHY AND OTHER IMAGING?

(out-of-pocket payments for imaging investigation (x-rays, CT-scan, ultrasound), TB-specific and other) (USh)

How much out-of-pocket money did you spend during this visit for: LAB TESTS?

(out-of-pocket payments for all tests) (USh)

How much out-of-pocket money did you spend during this visit for: OTHER PROCEDURES?

(out-of-pocket payments for biopsy, bronchial lavage, other surgery related to symptoms etc.)

How much out-of-pocket money did you spend during this visit for: MEDICINES?

(Any medicine prescribed for the participants symptoms)

How much out-of-pocket money did you spend during this visit for: ANY OTHER MEDICAL PAYMENTS?

How much out-of-pocket money did you spend during this visit for: TRAVEL?

(out-of-pocket payments for travel to facility (does not include income loss), for both participant and any household member)

How much out-of-pocket money did you spend during this visit for: FOOD?

(out-of-pocket payment for addition food bought in relation to travelling to the health care visit, and during visit or hospitalisation, for both participant and any household member)

How much out-of-pocket money did you spend during this visit for: OTHER EXPENSES INCLUDING ACCOMMODATION?

(includes out-of-pocket payments related to rent a room/bed during health care visits, and any other non-medical payments related to health care visit, for both participant and any household member).

Did you get any health insurance reimbursement for this visit? If so how much? 
(amount reimbursed to participant through medical insurance (private or public scheme) so far, does not include expected future

reimbursement)

If participant is not insured, write "0"

How much money did you lose by not working and instead attending

this facility?

(if the participant is salaried, or if the participant is unemployed, this may be "0")

\section{For interviewer}

Did the participant complete the survey?

If no, what question did they stop at?

$77 a$

If no, what question did they stop at?

If no, why not?

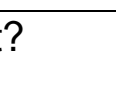

\begin{tabular}{|c|c}
80 \\
\end{tabular}

Field only to open if answer to question 78 is no.

Had to leave early

Survey was too long Issues with survey content Other (specify free text) 